\title{
Refrigerated water dispersion at the São Sebastião Channel
}

\author{
Jacyra Soares ${ }^{1}$, Belmiro M. Castro ${ }^{2} \&$ E. Eric Adams ${ }^{3}$ \\ ${ }^{1}$ Instituto Astronômico e Geofísico da Universidade de São Paulo \\ (Rua do Matão 1226, 05508-900 São Paulo, SP, Brasil) \\ ${ }^{2}$ Instituto Oceanográfico da Universidade de São Paulo \\ (Caixa Postal 66149, 05315-970 São Paulo, SP, Brasil) \\ ${ }^{3}$ Massachusetts Institute of Technology, Department of Civil and Environmental Engineering \\ (Room 48-325, Cambridge, MA 02139, USA)
}

- Abstract: This study examines numerically the fate of cooled ocean water discharged into the coastal ocean. The ocean water will eventually be used to warm up petroleum liquid gas during transference from ship tanks to land tanks, being cooled during the process. The refrigerated water will then be released vertically through a single port located at 2 meters below the surface in $15 \mathrm{~m}$ of water. The proposed operations will take place at the São Sebastião Channel located between the continent and the São Sebastião Island, at about $23^{\circ} 48^{\prime} \mathrm{S}, 045^{\circ} 22^{\prime} \mathrm{W}$. Estimated mean temperature differences between the effluent and the recipient sea water will be at most $3^{\circ} \mathrm{C}$. The problem is treated by analogy to an upsidedown (buoyant) thermal discharge using established initial mixing models developed by the US Environmental Protection Agency. During summer, when ambient stratification is high, the effluent plume is evanescent: it reaches the bottom with a temperature greater than the ambient, bounces back towards the surface and reaches equilibrium $10 \mathrm{~m}$ below the surface. During winter, on the other hand, the plume is bottom confined: it reaches the bottom with a temperature slightly lower than the ambient, remaining at that level. Model results also show that for any ambient ocean conditions the mixing time scale is of order of minutes and the final plume concentration obtained by mixing is smaller than $10 \%$.

- Resumo: Este estudo examina numericamente a descarga de água refrigerada em águas oceânicas costeiras. A água do mar será utilizada para aquecimento do gás liqüefeito de petróleo durante sua transferência dos tanques do navio para o continente, sendo resfriada durante esse processo. A água refrigerada será liberada, através de um único duto localizado a 2 metros abaixo da superficie, em um local cuja profundidade é de 15 metros. Essa operação será realizada no Canal de São Sebastião, localizado entre o continente e a ilha de São Sebastião, em cerca de $23^{\circ} 48^{\prime} \mathrm{S}, 045^{\circ} 22^{\prime} \mathrm{W}$. A diferença média da temperatura entre o efluente e a água oceânica receptora será de no máximo $3^{\circ} \mathrm{C}$. $\mathrm{O}$ problema é tratado aqui de forma análoga ao problema de descarga termal (empuxo), utilizando modelos de mistura iniciais desenvolvidos pela Agência de Proteção Ambiental dos EUA. Durante o verão, quando a estratificação é grande, a pluma é evanescente: ela alcança o fundo oceânico com temperatura maior do que a do ambiente, voltando em direção a superfície e alcançando o equilíbrio a 10 metros de profundidade. Durante o inverno, por outro lado, a pluma fica confinada ao fundo oceânico, alcançando o fundo com temperatura ligeiramente menor que o ambiente, permanecendo nesse nível. Resultados do modelo também mostram que para qualquer condição oceânica local a escala temporal de mistura é da ordem de minutos e a concentração final da pluma obtida pela mistura é menor do que $10 \%$.

- Descriptors: Dispersion, Refrigerated water, São Sebastião Channel, Thermal impact, Thermal plume, Negative buoyancy, Buoyant discharge.

- Descritores: Dispersão, Água refrigerada, Canal de São Sebastião, Impacto térmico, Pluma térmica, Empuxo negativo. 


\section{Introduction}

The buoyant plume problems of major interest to scientists and regulators have typically involved the discharge of lighter material into denser environment, such as a smoke plume in the atmosphere or freshwater sewage effluent discharged into the marine environment. The subjects of subsurface and surface discharges of large heated effluent flows as for example from thermal electric power plants are treated in many reports (Marmoush et al., 1984; Ward Jr., 1982; Hofer \& Kutter, 1981; Barry \& Hoffman, 1972; Adams, 1982; Jirka, 1982).

Here a special class of buoyant plume is investigated: the negatively buoyant plume (also called anti-thermal discharge). Some industrial wastes discharged to marine water have sufficient dissolved or suspended solid concentrations so that the bulk density is greater than the receiving waters into which they are discharged. Another case is the discharge of an effluent cooler than its environment. This kind of problem, although rare, has usually been studied by recasting the problem in terms of an analogous positively buoyant case.

Very few works exist in the literature about anti-thermal discharge. The best known example is the thermal freshwater plume discharged to freezing ambient freshwater (e. g., Frick \& Winiarski, 1978). As this plume cools by mixing with water near the freezing point it becomes denser than the ambient because the maximum density of freshwater is around $4^{\circ} \mathrm{C}$. Thus, if the temperature of the ambient is less than $4^{\circ} \mathrm{C}$, the potential for the nascent dense plume exists. Thermal and anti-thermal discharges, however, are physically similar because both are subjected to buoyancy forces, ambient flow and ambient density stratification.

This work investigates numerically the behavior of refrigerated ocean water which will eventually be discharged into the São Sebastião Channel. There are plans for building a heat exchanger for warming up liquid gas during its transference from ship tankers to land deposits. The heating element would be ocean surface waters, which would be cooled during the process and then released back into the channel through a diffuser.

The diffusion and transport processes of the effluent within the channel will be separated in two parts spatially and temporally distinct: near field and far field analyses. The next section contains a description of both the São Sebastião Channel and the diffuser characteristics. In Sections 3 and 4 the environmental data and models, respectively, are presented. Section 5 describes the numerical experiments and their results. Finally, Section 6 contains a discussion and the conclusions attained.

\section{The São Sebastião Channel and the diffuser}

The São Sebastião Channel (SSC) is a coastal channel located between the continent and the São Sebastião Island (SSI). Its orientation changes from NE to $\mathrm{N}$, in the southern and northern parts, respectively (Fig. 1). The channel is about 22 $\mathrm{km}$ long and wider in both entrances $(7.2 \mathrm{~km}$ and 5.6 $\mathrm{km}$ in the south and north, respectively) than in the middle $(1.9 \mathrm{~km})$. The $20 \mathrm{~m}$ isobath parallels the channel margins, and the maximum depth of about $45 \mathrm{~m}$ is located in the channel central and narrowest part.

The SSC is a highly energetic region where strong wind-driven currents, mixing of water masses of contrasting origins and a well defined seasonal thermocline accompanied by a two-layer baroclinic structure can be observed. There are not many published studies about the SSC physical oceanography, and most of them are concerned with the circulation. The latter has no strong correlation with the tides, but is highly influenced by the wind (Emilsson, 1962; Kvinge, 1967; Castro, 1990; Fontes, 1995). Castro (1985) applied a barotropic nested numerical model to study the SSC response to the wind-stress forcing during winter, being able to show that currents in the SSC are not entirely locally forced. Residual surface and bottom currents flow predominantly towards NE, although events showing southward currents are frequent.

There is a strong seasonal signal in the vertical density structure. During winter the waters are almost homogeneous, while during summer there is a strong thermocline usually between mid-depths and the bottom, resembling a two layer stratification (Silva, 1995; Coelho, 1997). The seasonal hydrographic variability within the SSC follows closely the one observed in the adjacent inner shelf (Castro, 1996).

The cold water outfall will eventually be located about midway between the SSC entrances, closer to the continent than to the SSI (Fig. 1). Local depth at the projected release point is $15 \mathrm{~m}$. The refrigerated water will be released vertically downward through a single circular diffuser (diameter of $76 \mathrm{~cm}$ ) $2 \mathrm{~m}$ below the surface. The eventual discharge will be continuous and attain a maximum of about $4250 \mathrm{~m}^{3} / \mathrm{h}$. The estimated temperature difference between the effluent and the recipient sea water will be at most $3^{\circ} \mathrm{C}$. The effluent will have the same salinity as the ambient. 


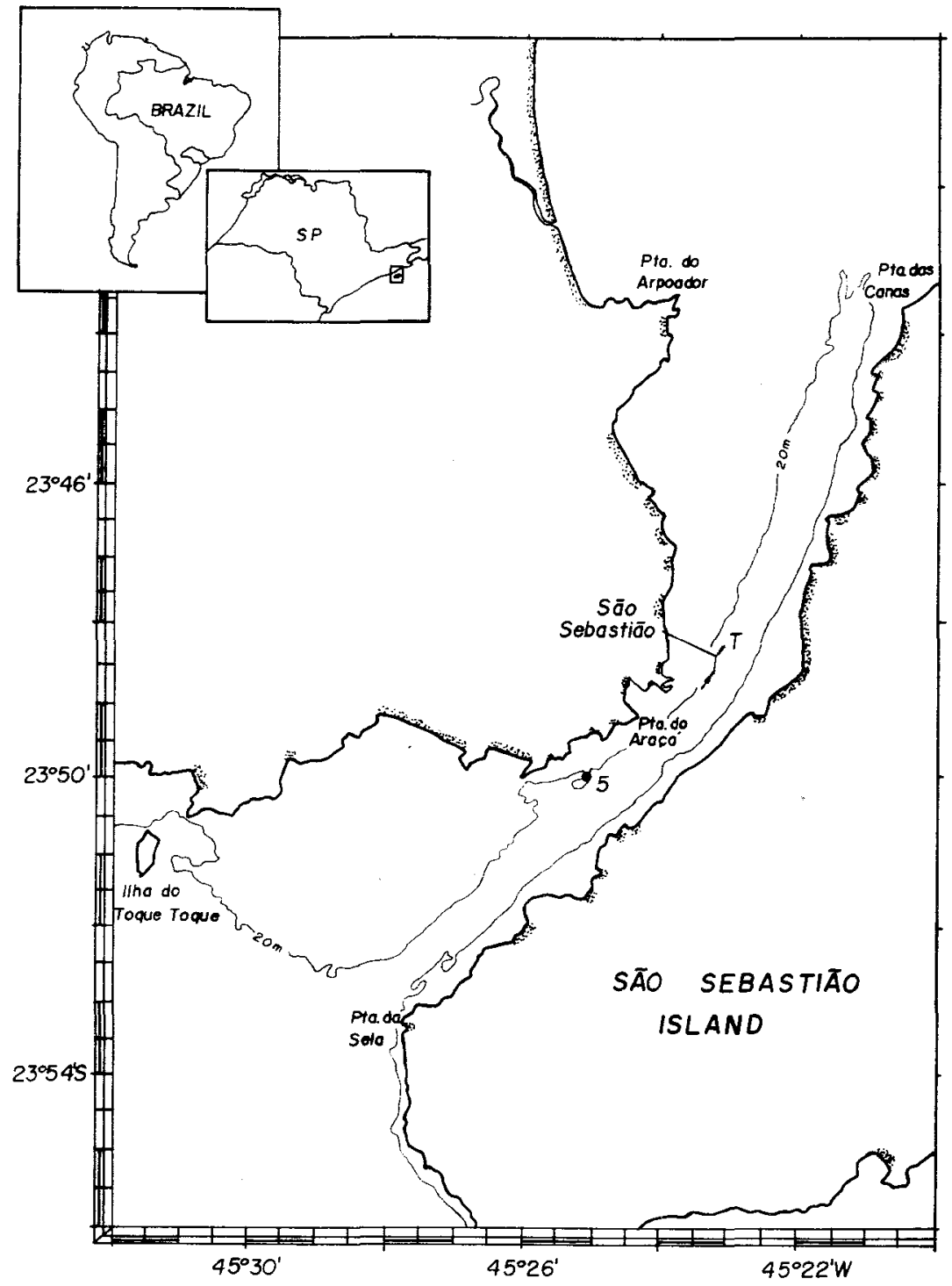

Fig. 1. São Sebastião Channel and location of the station where the data were collected.

\section{Ambient data}

The principal environmental variables to consider in dilution predictions are the ambient density stratification and currents. Therefore, vertical profiles of temperature, salinity and current velocity have been analyzed to obtain the seasonal patterns used as initial conditions for the simulation models.

Data used in this work was collected near the release point (Station 5, Fig. 1) as part of the project "Hydrodynamics of the São Sebastião Channel (HIDROCASS)" (Castro \& Miranda, 1995). Instantaneous vertical CTD and current meter profiles were obtained from an anchored boat during 19 field campaigns carried out during a time period of 2 years (from November, 1991 to December, 1993).

The data analysis main objective was to find the worst ambient conditions for the effluent mixing, or typically high vertical stratification and low current speeds. Near the projected release point thermal stratification was small during winter and current intensity varied between 0.25 and $0.32 \mathrm{~m} / \mathrm{s}$ (Fig. 2 - continuous line). During summer, however, the water was much more stratified, with temperatures of about $26^{\circ} \mathrm{C}$ at sea surface and $18^{\circ} \mathrm{C}$ near the bottom, and the weakest measured currents had speeds always below $0.2 \mathrm{~m} / \mathrm{s}$ (Fig. 2 - broken line).

\section{Models}

\section{Near field model}

Dispersion studies usually begin with a description of the plume behavior in the region located inside the zone of initial dilution. In this zone, near the diffuser, mixing is controlled by the combined effects of momentum and buoyancy of the 
discharged fluid, and by the ambient turbulence. Time and space scales are typically of the order of minutes and tens to hundreds of meters, respectively. The rate of dilution is quite rapid in the first few minutes after the jet exits the diffuser, decreasing markedly after the effluent initial momentum is dissipated and the buoyancy contrasts are attenuated. The initial dilution is usually also dependent on the ambient current speed.

In this paper the initial dilution region is treated by analogy to an upside-down (buoyant) thermal discharge. The well known Integral Plume Model, developed by Baumgartner et al. (1993), is used. The model reduces the essentially three dimensional problem to a numerical one dimensional problem by integrating over the cross-section of the plume using the assumption of self-similarity. Part of the model output is the dilution and the plume geometry (thickness, width, vertical elevation in the water column).

Model formulation is Lagrangian and it uses the projected area entrainment hypothesis which is a statement of forced entrainment - the rate at which mass is incorporated into the plume in the presence of current (Lee et al., 1987; Cheung, 1991).

Entrainment is the process by which the plume incorporates ambient material into itself. It may be thought of as a process in which fluid flows into the plume interior through the exterior surface. Alternatively, it may be considered to be a process of accretion followed by the redistribution of material. The model used here is consistent with the projected area entrainment hypothesis.

Several mechanisms of entrainment are considered: aspirated, forced, and turbulent (or eddy diffusion). Aspirated (also called jet or Taylor) entrainment is present even in the absence of currents. It is due to the fact that high velocity regions, as the initial jet, have relatively low pressures. The consequent pressure gradient force induces movements of the surrounding ambient water into the plume. Forced entrainment is due to the presence of currents which advect mass into the plume. Diffusion is assumed to be always present, but it is really important only beyond the initial dilution zone. It becomes dominant after the other two entrainment mechanism die off due to the steady reduction in shear between the plume and the ambient. This transition separates the near field from the far field.

Entrainment through the projected area of the plume is composed of three terms. The first term is proportional to the length and radius of the element (the cylinder component), the second to the growth in diameter of the plume, and the third to the curvature of the plume trajectory that opens or closes area on the element surface. All are simply mathematical parts of the overall projected area that contribute to forced entrainment. A fourth term, encompassing the entire peripheral area, accounts for aspiration entrainment.

When adjacent plumes grow sufficiently they begin to merge and entrain each other. Merging of plumes has the immediate effect of reducing entrainment by reducing the contact area between the plume and its environment. Each of the four entrainment terms is decremented to a different degree as merging proceeds. In essence, merging simply necessitates some geometric corrections. Here, only the merging of adjacent plumes discharging from linear diffuser are considered.

The plume is assumed to be in steady state, implying that successive elements follow the same trajectory. The steady state assumption is used to derive the length of the plume element as a function of the instantaneous average velocity, its initial length, and the initial effluent velocity (Baumgartner et al., 1993).

The Integral Plume Model includes statements for conservation of total mass, momentum and energy. Conservation of total mass states that the initial mass may be changed only by entrainment:

$$
\frac{\mathrm{dm}}{\mathrm{dt}}=-\rho_{\mathrm{a}} \overrightarrow{\mathrm{A}}_{\mathrm{P}} \cdot \overrightarrow{\mathrm{U}}+\rho \mathrm{A}_{\mathrm{t}} \mathrm{v}_{\mathrm{t}}
$$

where $\mathrm{dm}$ is the incremental amount of mass in the time increment $\mathrm{dt} ; \rho_{\mathrm{a}}$ and $\rho$ are the local ambient and average element densities, respectively; $\vec{A}_{P}$ is the projected area; $\vec{U}$ is the average velocity of the ambient flow through the projected area; $A_{t}$ is the area of the plume element in contact with the ambient fluid and $v_{t}$ is the Taylor aspiration speed. The first term on the right side of equation (1) represents the forced entrainment, and the second term represents the aspirated entrainment. Further details are available in Lee et al. (1987), Cheung (1991) and Frick (1984).

The momentum equation is:

$$
\frac{d}{d t}(m \vec{V})=\vec{U} \frac{d m}{d t}-m\left(\frac{\rho_{a}-\rho}{\rho}\right) \vec{g}
$$

where $\vec{V}$ is the average ambient velocity and $\vec{g}$ is the gravity vector. Equation (2) states that the change in momentum in the element is due to the amount of momentum introduced by the entrainment mass $(\mathrm{dm})$ and the change in vertical momentum generated by the buoyant force. The implicit assumption is that drag effects are absent. This is consistent with the 
conception of the element having the same properties as the ambient on the outside surfaces of the element. Effectively, there are no shears that can generate drag.

The momentum equation includes the reduced gravity term, which must be determined. Here, densities are derived from the equation of state used by Teeter and Baumgartner (1979).

The model uses the following thermodynamic equation:

$\frac{d}{d t}(m T)=T_{a} \frac{d m}{d t}$

where $T$ and $T_{a}$ are the average element temperature and ambient temperature, respectively. According to equation (3) the total variation of energy is due to the thermal energy introduced by the incorporated mass $\mathrm{dm}$. Radiation, conduction and diffusion processes are not important in this stage of mixing.

Conservation of salinity is expresses by:

$\frac{\mathrm{d}}{\mathrm{dt}}(\mathrm{ms})=\mathrm{S}_{\mathrm{a}} \frac{\mathrm{dm}}{\mathrm{dt}}$

where $S$ and $S_{a}$ are the average element salinity and the ambient salinity, respectively.

In order to close the problem, boundary conditions must also be specified. For the effluent these include the discharge flow rate, temperature and salinity. For the receiving ambient these include vertical profiles of current speed and density stratification, and the location of the source (from which the subsequent position of the plume element may be determined) and the initial plume radius.

\section{Far field model}

The second part of the problem pertains to horizontal distances greater than about $100 \mathrm{~m}$ from the point of discharge, where mixing is governed by ambient processes rather than the momentum and buoyancy of the discharge. Time scales range from tenths of minutes to hours. The far field model was applied when the plume reached its maximum fall. Due to the low concentration values obtained at the end of the near field analysis, a comparatively simpler model was chosen to study the far field problem. This model is known as Transient Plume Model (Baumgartner et al., 1993).

Output from the Integral Plume Model is automatically fed as input to the Transient Plume Model. This last also uses the ambient average velocity. Output from the far field model consists of the plume dilution as a function of its horizontal position along the trajectory.
The Transient Plume Model considers that the dilution caused by the transport of the contaminant to a new ambient is:

$$
C=\frac{C_{a}}{\operatorname{erf}\left(\sqrt{\frac{b^{2}}{16 \alpha b^{\frac{4}{3}} t}}\right)}
$$

where erf is the error function; $\mathrm{C}$ is the centerline concentration; $\mathrm{C}_{\mathrm{a}}$ and $\mathrm{b}$ are the centerline concentrations and the width of the plume at the end of the near field mixing, respectively; $\alpha b^{\frac{4}{3}}$ is a dispersion coefficient (Okubo, 1962; Fischer et al., 1979) and $t$ is the travel time from the point where the initial dilution ends.

\section{Results}

We have selected results from two numerical experiments to illustrate the physical behavior of the anti-thermal discharge. The data used as input to winter and summer experiments are shown in Figure 2. The near field model was run from the release moment until the effluent reached a stable position in the water column. From that point the far field model was applied considering the ambient velocity existing at the equilibrium level.

The fundamental physical variable of the buoyant jet (or forced plume) in a fluid is the density of the issuing fluid. The characteristic dimensionless parameter that governs the mechanics of the buoyant jet is the exit densimetric Froude number, defined by:

$$
\mathrm{F}_{0}=\frac{\mathrm{u}_{0}}{\sqrt{\frac{\mathrm{gD} \boldsymbol{D} \rho}{\rho}}}
$$

where $u_{0}$ is the effluent discharge velocity, $D$ is the nozzle diameter, $\mathrm{g}$ is the acceleration of gravity and $\Delta \rho$ is the initial density difference between jet and ambient fluid at port depth $(2 \mathrm{~m})$. This parameter describes the ratio of the sum of all forces per unit mass, $\mathrm{u}_{0}^{2}$, to the buoyancy force per unit mass, $g D$ $\Delta \rho / \rho$ of the fluid.

When $F_{0} \rightarrow \infty$, inertia dominates, and the buoyant jet behaves like a pure momentum jet. Conversely, when $F_{0}$ is small, buoyancy dominates, and a plume-like motion arises. In the intermediate case when $\mathrm{F}_{0}$ has a finite value, both inertia and buoyancy effects are important. The Froude number obtained for the summer and winter conditions were 45.6 and 36.5 , respectively, suggesting that the inertia force is always dominant but somewhat more important in the summer case. 

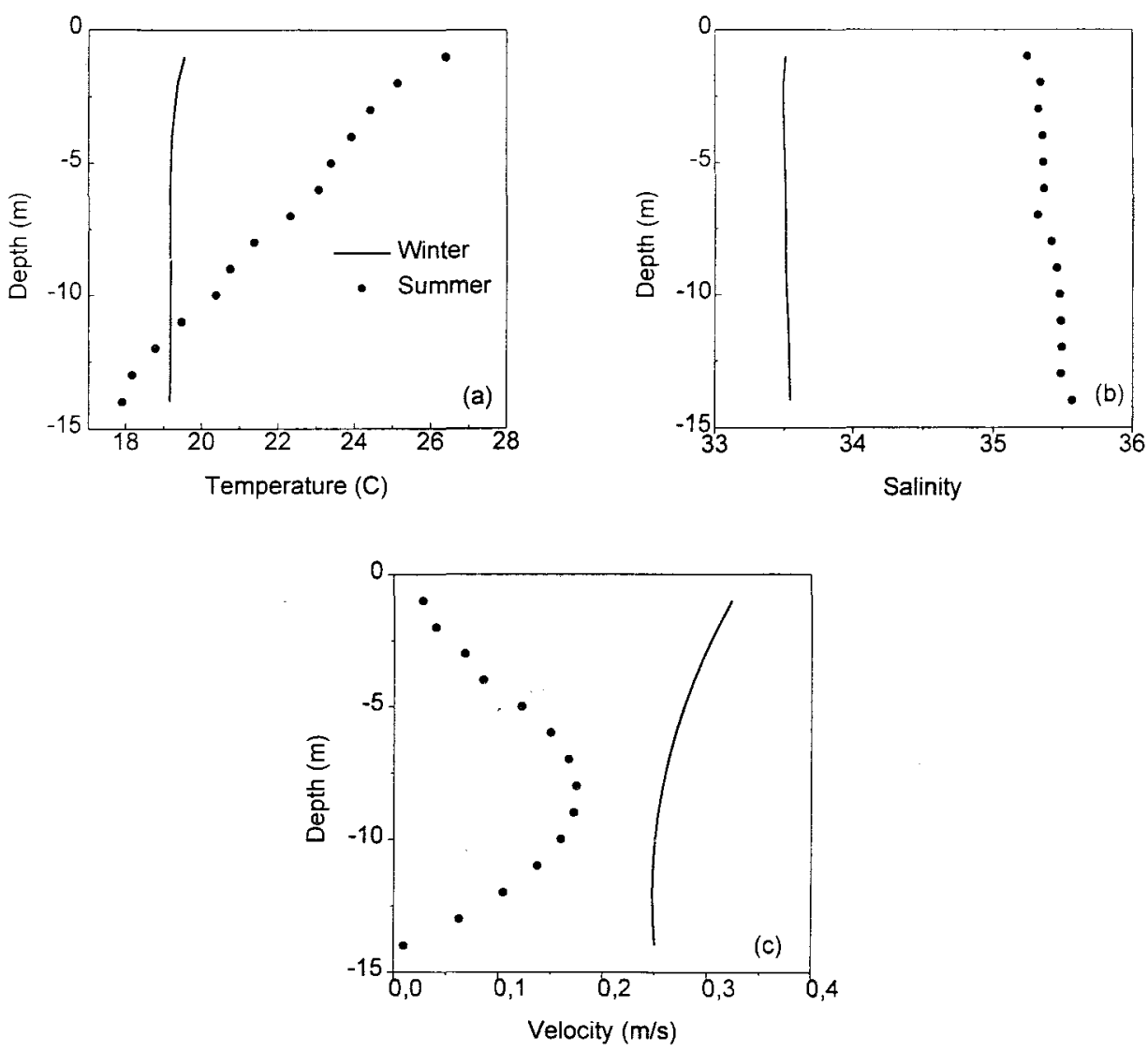

Fig. 2. Vertical profiles of (a) temperature, (b) salinity and (c) current along the São Sebastião Channel. Summer condition (broken line). Winter condition (continuos line).

Results for the near field analysis are presented in Figure 3. The figure displays the ocean ambient temperature (continuous line) and the effluent centerline temperature (broken line) as a function of depth. For the summer experiment the plume reaches the ambient temperature $\left(T_{A}\right)$ at a depth of $4 \mathrm{~m}$, or after a vertical displacement of only $2 \mathrm{~m}$ (Fig. 3a). After reaching $\mathrm{T}_{\mathrm{A}}$ the plume continues its descending motion down to the ocean bottom due to its vertical momentum. As the plume descends in the water column, it rapidly warms through entrainment. When reaching the bottom the plume centerline shows an effluent concentration of about $9 \%$ and a temperature $3^{\circ} \mathrm{C}$ higher than the near bottom ambient temperature (Table 1). The negative temperature difference induces a positive (upward) buoyancy able to rise the plume from the bottom to the $10 \mathrm{~m}$ level, where it finds its static stability level. When reaching the equilibrium level the plume temperature is identical to that of the surrounding water, and the plume physically disappears almost instantaneously, without oscillations. In this case the plume could be called evanescent. Plume diameter at the ocean bottom was about $10 \mathrm{~m}$. In this case, the effluent descending motion can be considered practically vertical: the horizontal distance between the plume centerline at the discharge depth and at the ocean bottom was only $3 \mathrm{~m}$.

During the winter experiment (Fig. 3b) the plume temperature $\left(T_{P}\right)$ remained smaller than the ambient temperature throughout the descending motion. At the end of the near field analysis, plume temperature was only $0.06^{\circ} \mathrm{C}$ smaller than the ambient water temperature. This small temperature difference went to zero in a radius of order of $7 \mathrm{~m}$. Consequently, the plume reached the ocean bottom practically with the same density as that of the ambient water, tending to remain at that level. In this case the plume could be called bottom confined. The effluent concentration was small $(2.7 \%)$ and the plume presented a diameter of $14.5 \mathrm{~m}$ near the ocean bottom. Plume descending trajectory was more deflected from the local vertical than in the previous experiment: the horizontal distance between the centerline effluent at surface and bottom was about 12 meters. 
(a) Summer

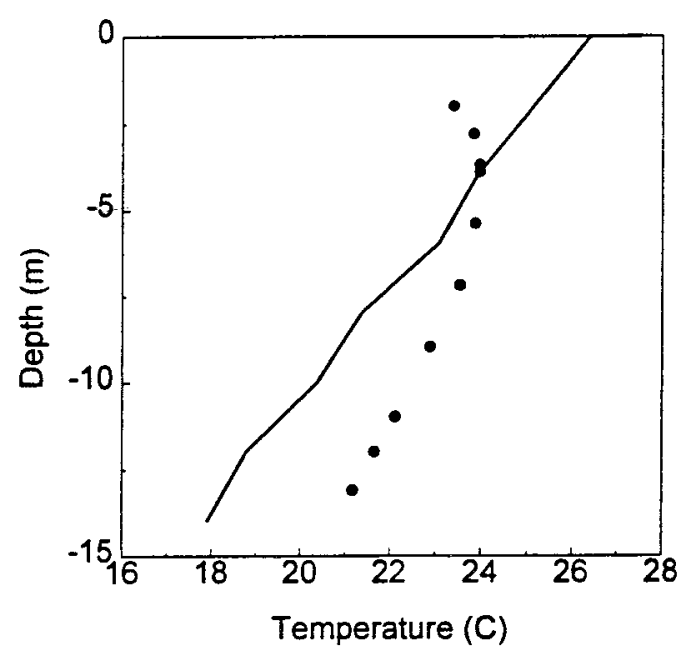

(b) Winter

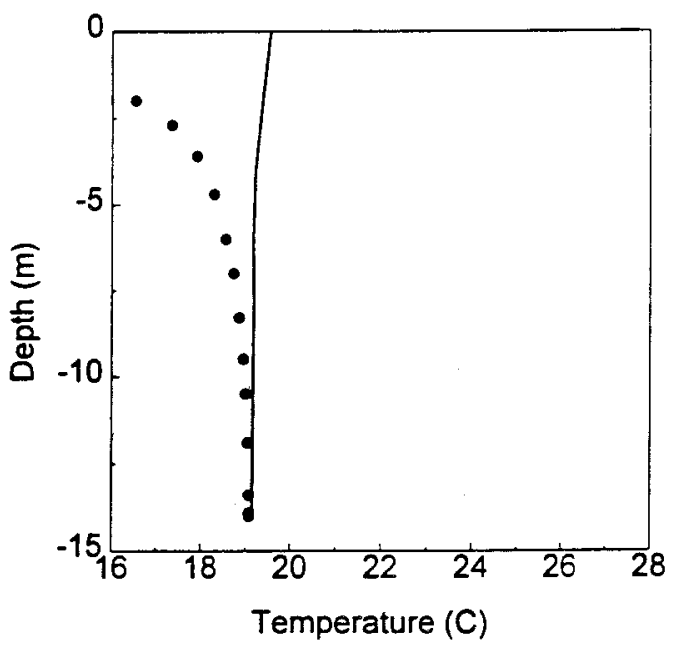

Fig. 3. Ambient ocean water temperature (continuous line) and near field plume centerline temperature (broken line), in ${ }^{\circ} \mathrm{C}$, as a function of depth, in meters. (a) Summer and (b) winter conditions.

Table 1. Results obtained near the ocean bottom during the near field analysis. $T_{A}$ and $T_{P}$ are the ambient water and centerline plume temperature, respectively.

\begin{tabular}{|l|c|c|}
\cline { 2 - 3 } \multicolumn{1}{c|}{} & SUMMER & WINTER \\
\hline Plume concentration $(\%)$ & 8.9 & 2.7 \\
\hline Plume diameter $(\mathrm{m})$ & 10.0 & 14.5 \\
\hline Along channel distance $(\mathrm{m})$ & 3 & 12 \\
\hline $\mathrm{T}_{\mathrm{A}}-\mathrm{T}_{\mathrm{P}}\left({ }^{\circ} \mathrm{C}\right)$ & -3.18 & 0.06 \\
\hline
\end{tabular}

Results for the far field analysis performed for the winter conditions are shown in Table 2. The plume speed used in the experiment corresponds to the observed value near the ocean bottom, $0.25 \mathrm{~m} / \mathrm{s}$ (Fig. 2c - continuos line).

Table 2. Results obtained at the end of the far field analysis for winter, when the plume is $800 \mathrm{~m}$ away from the discharge point.

\begin{tabular}{|l|c|}
\cline { 2 - 2 } \multicolumn{1}{c|}{} & WINTER \\
\hline Ambient velocity $(\mathrm{m} / \mathrm{s})$ & 0.25 \\
\hline Plume concentration $(\%)$ & 1 \\
\hline Time $(\mathrm{h})$ & 0.9 \\
\hline
\end{tabular}

At the end of the far field analysis both the plume concentration and temperature difference between the ambient and the plume were very small, $1 \%$ and $0.03^{\circ} \mathrm{C}$, respectively. The plume reached, after $0.9 \mathrm{~h}$, an along channel horizontal distance of $800 \mathrm{~m}$ (Fig. 4).

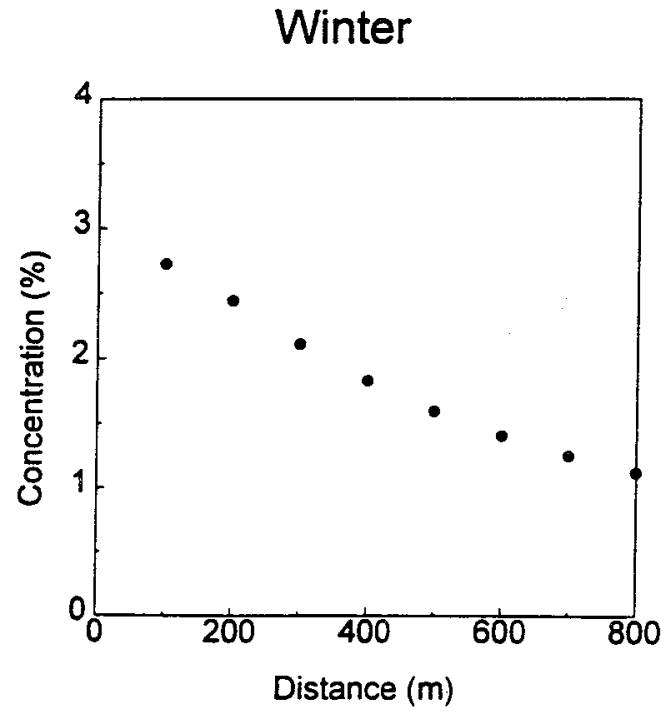

Fig. 4. Far field plume concentration (\%) as function of the distance along the São Sebastião Channẹl (in meter).

\section{Discussion and conclusions}

The ambient vertical density stratification is the main factor responsible for the contrasting modeled plume behavior. During summer, when the vertical density stratification is high, the plume behavior is evanescent. In this case the plume bounces back towards the surface after reaching the ocean bottom. The plume descending motion is controlled basically by the initial inertia at the 
diffuser. Buoyancy, on the other hand, controls the ascending motion, since the plume reaches the bottom with a temperature higher than the surrounding sea water. During winter the vertical density stratification is low, and the plume tends to be confined near the bottom. This is due to the very small positive temperature difference between the surrounding water and the plume at the end of the descending motion.

The thermal impact of the effluent at the channel bottom can be called positive or negative, depending on whether the plume temperature is higher or lower than the surrounding water. Positive thermal impacts are associated to evanescent plumes and negative impacts to bottom confined plumes.

Positive thermal impacts occur during summer, when the thermal stratification of the water column is large. In this situation there is no far field mixing, since the plume reaches the equilibrium level with the same physical characteristics as the environment. The summer positive impacts are then local, reaching a maximum radius of the order of ten meters.

Negative thermal impacts are observed during winter, when the water column thermal stratification is small. During the far field mixing the bottom confined effluent is advected by the bottom currents, covering a larger area of the ocean bed than that associated to the evanescent plume. Experiments have shown that the plume horizontal displacement can be of the order of $1 \mathrm{~km}$ in about 1 hour.

Concluding, bottom positive thermal impacts during summer display larger temperature differences between the effluent and the ambient but they are local phenomena. Bottom negative thermal impacts during winter, on the other hand, present smaller temperature differences between the effluent and the ambient but they extend for a larger area of the channel bottom.

Ambient currents will also influence the rate of dilution during plume sinking irrespective of jet momentum and buoyancy. Under low currents the plume will be retained closer to the diffuser. Entrained organisms and near-bottom resources are more at risk under this scenario.

\section{Acknowledgments}

This work was supported by PETROBRAS. The first and second authors were recipients of grants number 300040/94-6 and 303877/86-3, respectively, from $\mathrm{CNPq}$.

\section{References}

Adams, E. E. 1982. Dilution analysis for unidirectional diffusers. J. Hydraul. Eng.-ASCE, 108(3):327-342.

Barry, R. E. \& Hoffman, D. P. 1972. Computer model for thermal plume. J. Power Div.- ASCE, 98:117-132.

Baumgartner, D. J.; Frick, W. E. \& Roberts, P. J. W. 1993. Dilution models for effluent discharges. Environ. Res. Lab., N268. 185p.

Castro, B. M. 1985. Subtidal response to wind forcing in he South Brazil Bight during winter. Tese de Doutorado. Miami, University of Miami. $211 \mathrm{p}$.

Castro, B. M. 1990. Wind driven currents in the Channel of São Sebastião: winter, 1979. Bolm Inst. oceanogr., S Paulo, 38(2):111-132.

Castro, B. M. 1996. Correntes e massas de água da plataforma continental norte de São Paulo. Tese de livre docência. Universidade de São Paulo, Instituto Oceanográfico. 248 p.

Castro, B. M. \& Miranda, L. B. 1995. Projeto Hidrodinâmica do Canal de São Sebastião (HIDROCASS). Relatório Final. São Paulo, FAPESP. $96 \mathrm{p}$.

Cheung, V. 1991. Mixing of a round buoyant jet in a current. Tese de doutorado. Hong Kong, University of Hong Kong.

Coelho, A. L. 1997. Massas de água e circulação no Canal de São Sebastião. Dissertação de mestrado. Universidade de São Paulo, Instituto Oceanográfico. 244 p.

Emílsson, I. 1962. Correntes marítimas no Canal de São Sebastião. Ciência Cult., S Paulo, 14(4): 269-270.

Fontes, R. F. C. 1995. As correntes no Canal de São Sebastião. Dissertação de mestrado. Universidade de São Paulo, Instituto Oceanográfico. $159 \mathrm{p}$.

Fischer, H. B.; List, E. J.; Koh, R. C. Y.; Imberger, J. \& Brooks, N. H. 1979. Mixing in inland and coastal water. New York, Academic Press. $483 \mathrm{p}$. 
Frick, W. E. \& Winiarski, L. D. 1978. Why Froude number replication does not necessarily ensure modeling similarity. In: CONFERENCE ON WASTE HEAT MANAGEMENT AND UTILIZATION, 2. Miami, 1978. Proceedings.

Frick, W. E. 1984. Non-empirical closure of the plume equations. Atmos. Environ., 18(4):653662 .

Hofer, K. \& Kutter, K. 1981. Turbulent jet diffusion in stratified quiescent ambients. 1: Theory. J. Non-Equil. Thermodyn., 6(1):31-48.

Jirka, G. H. 1982. Multiport diffusers for heat disposal: a summary. J. Hydraul. Eng. - ASCE, 108(12):1425-1468.

Kvinge, T. 1967. On the special current and water level variations in the Channel of São Sebastiấo (SP). Bolm Inst. oceanogr., S Paulo, 16(1):23-38.

Lee, J. H. W.; Cheung, Y. K. \& Cheung, V. 1987. Mathematical modelling of a round buoyant jet in a current: an assessment. In: INTERNATIONAL SYMPOSIUM ON RIVER POLLUTION CONTROL AND MANAGEMENT. Shangai, 1987. Proceedings. S62.
Marmoush, Y. R.; Smith, A. A. \& Hamblin, P. F. 1984. Pilot experiments on thermal bar in lock exchange flow. J. Energ. Eng. - ASCE, $110(3): 215-227$.

Okubo, A. 1962. A review of theoretical models of turbulent diffusion in the sea. Tech Report, 30.

Silva, L. S. 1995. Condições oceanográficas no Canal de São Sebastião e na região costeira adjacente: variações sazonais entre fevereiro de 1994 a março de 1995. Dissertação de mestrado. Universidade de São Paulo, Instituto Oceanográfico. $128 \mathrm{p}$.

Teeter, A. M. \& Baumgartner, D. J. 1979. Prediction of initial mixing for municipal ocean discharges. CERL Publ, 43.90 p.

Ward Jr., G. H. 1982. Thermal plume area calculation. J. Energ. Div. - ASCE, 108(2):104115.

(Manuscript received 06 February 1998, revised 24 August 1998; accepted 28 June 1999) 